\section{Greater financial accountability for UK higher education}

\section{London}

As part of its overhaul of the structure and planning of higher education, the British government is proposing to introduce stringent financial controls over universities, polytechnics and colleges. Strict auditing and accounting procedures are to be implemented in an effort to demonstrate greater control over public funds and to avoid a repetition of the sort of financial mismanagement that occurred at University College, Cardiff, which earlier this year required $£ 10$ million of government cash to pay off debts (Nature 327, $180 ; 1987)$.

Last week, the Department of Education and Science (DES) published a consultative document, Accounting and Auditing in Higher Education, emphasizing the need of institutions to demonstrate that "the resources made available to them are being applied economically, efficiently and effectively and for their intended purpose"

As part of its forthcoming education bill, the government intends to free polytechnics and colleges from the control of local authorities and to channel their funds through a Polytechnic and Colleges Funding Council (PCFC). The University Grants Committee will be replaced by a Universities Funding Council (UFC). An Education Assets Board (EAB) will be established, responsible for transferring assets to the polytechnics and colleges.

The government wants the Secretary of
State for Education to specify to the funding councils and the $\mathrm{EAB}$ the information should be presented. In turn, the funding councils will issue accounts directions to individual institutions.

Polytechnics and colleges will be required to follow present university practice and appoint external auditors. For all institutions the procedure for appointment and the appointment itself will, however, require the approval of the appropriate funding council. The funding councils will be required to "lay down a basic framework for the scope of the external audit". Such a framework the government foresees as including "whether institutions are complying with recommended practice; examination of accounting systems and internal controls for-money' monitoring is perplexing academics, who fear that the auditors will have the authority, against previously agreed principles, to encroach on academic judgments.

Within institutions, audit committees will be established, in broad compliance with a recommendation from a working group of the Committee of Vice-Chancellors and Principals. Such committees will comprise between three and six people, including senior lay staff, with the majority of the members of the governing body of the institution.

A temporary 'higher education internal to be contained in accounts and how it and 'value-for-money' work". The 'value- audit unit' will be established for an initial period of 3-5 years to give support and guidance to the funding councils, and will be responsible to the accounting officers of the DES. The unit would have right of access to the books of the councils and the institutions they fund. At present the DES has no right of access to the books of individual universities.

The clear implication from the consultative document is that present arrangements for financial accountability are too loose. Although most of the proposals will not be made law, adherence will be required as a condition of funding. Academics say that while accountability for public funds is proper, such strict arrangements could serve to stifle local initiatives.

Simon Hadlington

\section{Polish ministry is abolished}

\section{London}

POLAND last week abolished its Ministry of Science and Higher Education. A new Ministry of National Education will now cover the entire range from kindergarten to postgraduate. What will become of the "science" sector is not entirely clear. Questioned on Warsaw Television on Monday, the incoming Minister of National Education, Henryk Bednarski, said that it would be necessary to reorganize and rethink the entire structure. One possibility would be to transfer the science sector of the old ministry to the State Committee for Science and Technical Progress, established in December 1984 by hiving off technology from the then Ministry of Science, Higher Education and Technology. The main purpose of this committee was to inject additional investment into research likely to bring short- or middle-term economic returns. But it is not entirely clear, however, what the status of this committee will be now. Its functions could well be subsumed, at least some of them, into the new Ministry of Industry.

Whatever happens to the science sector of the old ministry, however, Polish science will not be without at least one ministerial voice. The academic secretary of the Polish Academy of Science holds ex officio ministerial rank (in return for which, his first responsibility is to the prime minister, not to the members of the academy). Unlike the situation in the Soviet Union, Polish scientists cannot simultaneously hold university and academy posts, so those working in Academy institutes will not be affected by the shake-up. But the other two domains of Polish science - the universities and the "branch" (sectoral) research institutes, the situation, at present, seem somewhat unclear.

Vera Rich 